\title{
Responsiveness and Renewal in Canada's Community Colleges: A Study of Change in Organizations
}

\author{
JOHN S. LEVIN* and JOHN D. DENNISON†
}

\begin{abstract}
This study deals with change in organizations. Specifically, the focus is upon Canada's community colleges during a period of economic and socio-political change in the 1980s. Canadian colleges, born and nurtured within an unprecedented era of postsecondary educational expansion in the $1960 \mathrm{~s}$, were founded upon ideals of democratization of opportunity, accessibility, adaptability, and comprehensiveness. This study examines if and to what extent the colleges have retained these principles in confronting external and internal forces during the last decade.

The theoretical model designed for the study involved a three-dimensional matrix in which theories of adaptation (Cameron, 1984) and power, (Mintzberg, 1979) form two dimensions. The third dimension is created from a variety of optional developmental models specific to the community college as an organization (McCartan, 1983; Cross, 1985; Dennison and Gallagher, 1986).

The results of the study revealed that much of the idealism and innovation which guided the colleges in earlier days was still to be found. However, in attempting to deal with increased direction from government, and from reduced fiscal support, the colleges have sought several ways to adjust or adapt. In doing so they have become more enterpreneurial, less community-oriented, and more tightly managed. Diversity, however, was also evident, as adaptive strategies differed widely in various regions across Canada.

By applying the matrix designed for the study, it was possible to determine that colleges were managing change by utilizing a variety of techniques. Change in community colleges involves a diversity of methods and produces a diversity of results.
\end{abstract}

\footnotetext{
*Kwantlen College

†University of British Columbia
}

This research has been carried out with the assistance of a grant from the Social Sciences and Humanities Research Council of Canada. 


\section{RÉSUMÉ}

La présente étude porte sur le changement dans les organisations, et plus particulièrement dans les collèges communautaires du Canada au cours d'une période de changement économique et socio-politique, dans les années 1980. Les collèges canadiens, qui ont vu le jour et grandi dans une période sans précédent d'expansion de l'éducation post-secondaire, dans les années 1960, reposaient sur des idéaux de démocratisation des débouchés, d'accessibilité, d'adaptabilité et d'universalité. L'étude examine dans quelle mesure les collèges ont conservé ces principes dans leurs confrontations avec des forces intérieures et extérieures, au cours de la dernière décennie.

Le modèle théorique conçu pour l'étude comprenait une matrice tridimensionnelle où les théories de l'adaptation (Cameron, 1984) et du pouvoir (Mintzberg, 1979) représentent deux dimensions. La troisième dimension est créée à partir de divers modèles de développement facultatif particuliers aux collèges communautaires en tant qu'organismes (McCartan, 1983; Cross, 1985; Dennison et Gallagher, 1986).

L'étude a révélé qu' une grande partie de l' idéalisme et de l'innovation qui ont guidé les collèges à leurs débuts étaient toujours là. Toutefois, les collèges ont cherché plusieurs manières de s'adapter ou s'ajuster en tenant de s'accommoder d'un contrôle gouvernemental plus rigoureux et d'un soutien financier réduit. Ce faisant, ils ont développé un esprit d'entrepreneur et sont devenus moins axés sur la communauté et mieux administrés. On a également relevé de la diversité alors que les stratégies d'adaptation variaient grandement d'une région l'autre du Canada.

L'application de la matrice conçue pour l'étude a permis d'établir que les collèges faisaient appel à des techniques variées pour faire face au changement qui, dans les collèges communautaires, fait intervenir des méthodes variées qui donnent des résultats divers.

\section{INTRODUCTION}

Community colleges and college systems in Canada developed during an unprecedented period of postsecondary educational expansion between 1960 and 1975. Each province and territory designed a unique model consistent with its educational and socio-cultural history, and in response to the political and economic conditions of the time. In most regions the initiative for college development came from government, either by direct legislative enactment, or through policies which allowed school boards and other community groups to establish college programs and services.

Largely because of their developmental history, Canadian colleges have established close relationships with their regional governments, a factor which has increased their dependency upon the latter for fiscal support and, in turn, limited 
their autonomy and ability to respond to community needs. The decade of the nineteen-eighties has introduced new pressures upon the colleges as overall political support for education has diminished in an unstable economic climate, together with an increasing concern for accountability from public sector organizations. Canadian colleges are vulnerable not only to policy initiatives from provincial governments, but also to the federal (national) government which plays both a direct and an indirect role, as do a variety of external agencies such as employee advisory committees, social organizations, and other levels of education and community services.

There has also been greater pressure from internal institutional constituencies, which has had an impact upon the colleges. Faculty organizations concerned about job security and the ordering of program priorities, a changing student clientele, administrators seeking managerial and technological innovation and, in some cases, more politicized boards have all contributed to the current level of instability in college operations.

There is little doubt that colleges in Canada are undergoing change, but to what extent, in which direction, and with what consequences, is unclear. Nor is it apparent who the primary players are in the inevitable power struggles which accompany change.

A further complication in attempting to diagnose the dynamics of change is the diversity which characterizes Canada's community colleges. As noted earlier, colleges in different regions have unique histories (Dennison \& Gallagher, 1986), pursue a variety of missions and goals, and retain varying degrees of control over their futures. Given the range of organizational structures, curricular patterns, and relations with their communities, any attempt to understand and evaluate change in these institutions must initiate from a model with broad general application.

Despite the diversity among Canada's college systems, however, an intensive analysis of the relevant literature from government, intermediary bodies, policy-making agencies and the institutions themselves, in each province, indicates that a limited number of common goals and purposes are embedded in all college systems. These purposes, which might be best classified as "common principles," are as follows:

The community college is a flexible social organization which can adapt to new student clienteles, structural changes in program delivery, technological changes in the workplace, and demand for new instructional techniques.

The community college provides increased access to educational opportunity for a broad cross section of people in its region.

The community college maintains a comprehensive curriculum, the latter includes both educational and training components.

The community college emphasizes commitment to teaching and concern for quality of instruction and student service.

The community college maintains the general community orientation which is reflected in its governance system and its program mix. 
By adopting these priorities, Canada's community colleges have brought a new era of educational opportunity to a cross-section of society which has traditionally been excluded from postsecondary education. In their short history, the colleges have experienced periods of growth, consolidation, and restraint (Dennison, 1987). In the last five years they have been required to respond to rapidly changing demands from many groups and to reassess their commitment to provide an extensive range of high quality educational experiences. The extent to which colleges have retained their original missions during the volatile climate of the nineteen-eighties remains a matter of conjecture.

This study was designed to examine change in colleges as organizations. How has change occurred? What is the direction and extent of change? Who are the agents of change? And, what kind of organization is emerging in the process?

\section{CONSTRUCTING A CONCEPTUAL FRAMEWORK}

In constructing a conceptual framework for the research problem, and for organizing the data, it proved useful to draw upon two distinct themes from the research literature. The first of these flowed from organizational theory, particularly that part of it dealing with change and adaptation in complex organizations. The second theme focused upon the community college as a particular form of organization and, as such, a specific context for study.

Two theories of organizational adaptation and change seemed most relevant as pillars on whcih to build the conceptual framework. Cameron (1984) describes a continuum which structures perspectives on forces of change. At one end of the continuum, the population ecology perspective, the external environment is conceived as playing the dominant role, and managers have no power to influence organizational adaptation. It is the environment, not the organization, which does the selecting (Miles and Cameron, 1982).

At the opposite end of the continuum, the symbolic action perspective, it is the managers who exercise the levers of change, largely independent of the influences of the environment, by providing meaning, sense, and purpose to the organization, and by building internal consensus for action (Pfeffer, 1981; Cameron, 1984). Managers utilize myths, symbols and rituals (Dill, 1982) to describe the environment for the members of the organization. In consequence, environments are interpreted by the organization, and the latter adapts to its own interpretation.

Between these two extremes are two less definitive perspectives on adaptation. The "life cycles" (Cameron and Whetten, 1981) perspective assumes predictable stages of organizational development, where the organization displays different features at each stage. Managers influence organizational adaptation by selecting the methods and decisions which are appropriate at each stage. At the "entrepreneurial" stage in the life cycle, the emphasis is on survival, growth and resource acquisition; whereas at the "collectivity" stage, the shift is to human resources and human relations. The "formalization" stage refers to an emphasis on processes, productivity, and efficiency; while at "elaboration of structure" stage, 
attention is focussed on renewal or expansion through increased connection to the external environment.

Finally, the second intermediary perspective on adaptation outlined by Cameron, "strategic choice", suggests that, although the external environment contributes to organizational adaptation, managers can modify the external environment, or choose strategies which will select favourable components of it, thereby reducing environmental influences (Miles and Snow, 1978). All of these perspectives and descriptions of organizational adaptation postulated by Cameron were deemed appropriate to the study of changes experienced by community colleges in the 1980s.

A second major theory of organizational behavior which seemed relevant was that of Mintzberg's theory of power (1979). Power configurations within an organization can be seen as sources for goal pursuit and suggest forces of organizational action. Mintzberg proposes six different power configurations:

a. Instrument: The organization (the college) serves a dominant external influence and its internal system is highly bureaucratic. "Such a configuration tends to emerge when an organization experiences external power that is focussed and organized, typically around a critical dependency" (Mintzberg, 1983), such as money or legal authority.

b. The Closed System: The dominant internal influencers are senior administrators who direct the organization towards system goals such as survival, efficiency, control and growth. This approach emphasizes the systematic pursuit of mission, and formalizes procedures.

c. The Autocracy: The organization revolves around the chief executive officer who, in turn, demands loyalty. The autocracy enables small organizations to function effectively and many of these which are either new or in crisis to survive.

d. The Missionary: The organization, dominated by a clear ideology, pursues the preservation and perfection of its mission, and, in turn, influences the external environment.

e. The Meritocracy: The organization focusses on its professionals who pursue diverse goals with a high level of expertise. Loyalty is directed more to the professional than the organization, and individual freedom of action prevails.

f. The Political Arena: Conflict within the organization dominates and no one group, internal or external, has control. The political arena induces necessary but resisted change within the power system.

After adopting the Cameron and Mintzberg theoretical positions, the next step is to determine their application to the community college environment. In matters of college functions, roles, or missions, three authors, McCartan (1983), Cross (1985), and Dennison and Gallagher (1986) take fairly similar positions on which options are open to community colleges on the matter of adaptation and change. These three positions also share common assumptions about organizations and organizational actions.

McCartan argues that colleges may either choose to adapt and respond to changing community needs (as a college for the community, or continue to 
provide traditional education services (as a college in the community), largely independent of the community. Some colleges will adopt not just one but a combination of both approaches. To Cross (1985), five alternative foci are open to a college: the "comprehensive", with a continuation of many programs for many people; the "vertical", which emphasizes the transfer function of the college programs; the "horizontal", which extends college linkages with the community, particularly with local industry and social organizations; the "integrated", which gives primary recognition to general education and broad student development; or the "remedial", which emphasizes educational aid for disadvantaged youth and disaffected minorities. Dennison and Gallagher (1986), with particular reference to colleges in the Canadian context, outline options not dissimilar to the Cross model, but also introduce the "life-long" learning response. The latter describes the college as an organization responsive to students of all ages, at all stages in their lives, by providing programs appropriate to their constantly changing needs.

These three treatments were sufficiently similar to permit their synthesis into a single set of alternatives, as shown below:

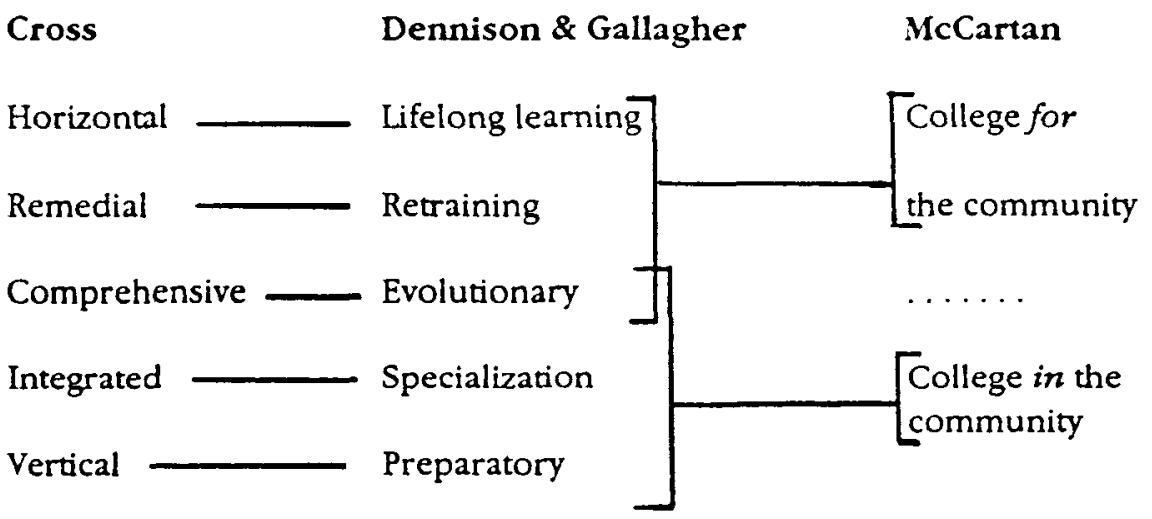

The final and most difficult task in the preparation of a conceptual framework is to construct a matrix which brings selected theories into a logical relationship with one another, while, at the same time, guiding the method, to ensure that both theory and practice accompany the data-gathering strategy in the study. To provide both meaning and direction to the strategy, a three-dimensional matrix was constructed. This model (figure 1) juxtaposes the Cameron and Mintzberg concepts of adaptation and power configurations, respectively, as two dimensions of the matrix. The third dimension of the matrix combines the McCartan, Cross, and Dennison and Gallagher options of role adaptation in community colleges, as described above. The horizontal (Cross) or lifelong learning (Dennison and Gallagher) approaches and the remedial constitute a college for the community (McCartan). Similarly, the integrated and vertical approaches will eventually define a college as one in the community. The comprehensive approach falls 
Responsiveness and Renewal in Canada's Community Colleges:

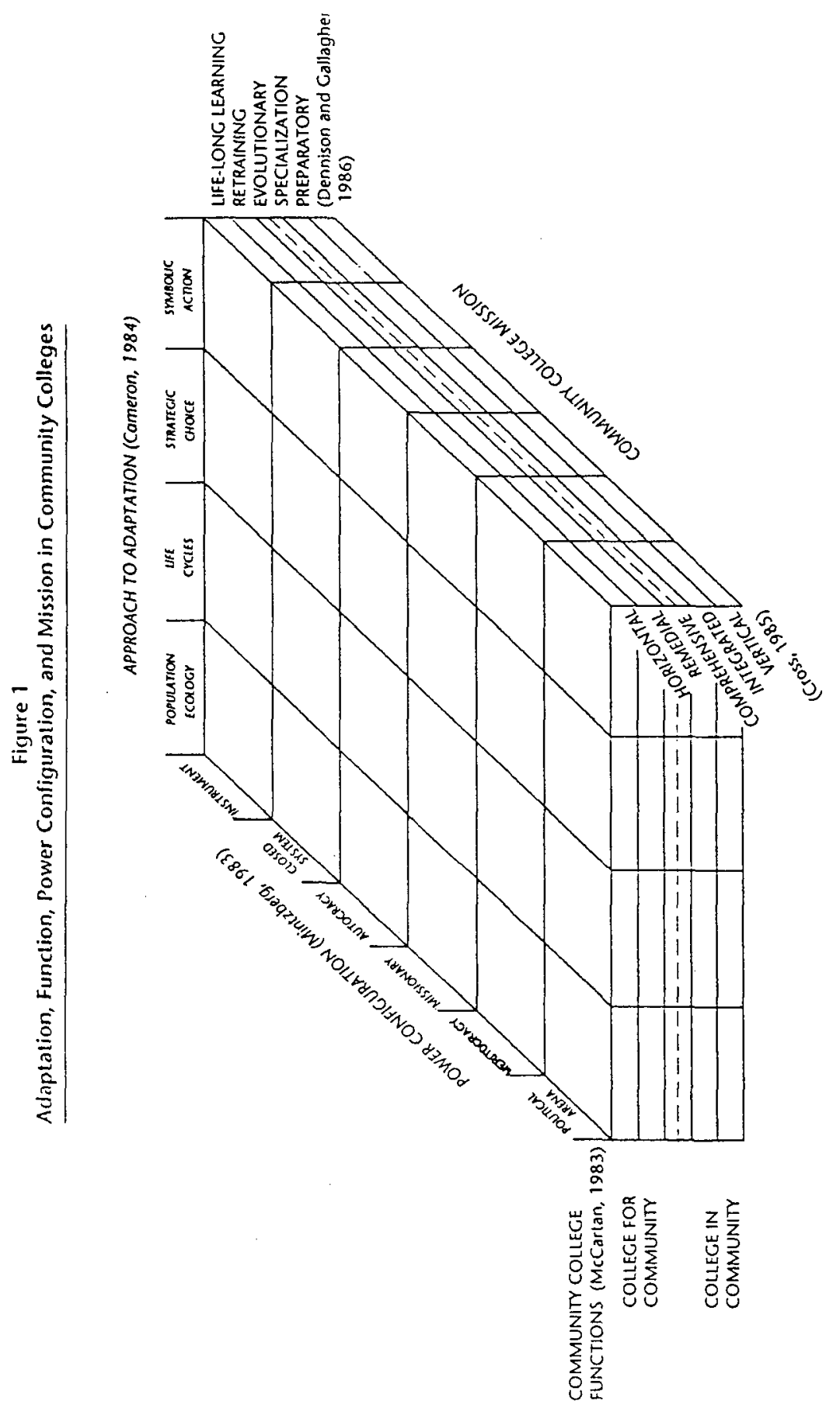

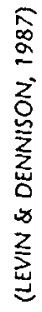


between the two other sets, and can often be seen as a combination of the other four approaches.

As indicated in figure 1, the matrix produces a series of three dimensional "cells," each of which characterizes a separate approach to action and change. For example, College X might be exhibited as becoming more firmly rooted in the community, by emphasizing both a "vertical" and a "remedial" focus. In doing so, college management might be seen as deliberately selecting policies and decisions to ensure the selected direction of change (i.e., using a "strategic" approach.) The power pressures which are exercised in driving the college in the above direction could be senior management operating within a bureaucratic structure. In other words, College $\mathrm{X}$ is utilizing an "instrument" and "closed-system" power configuration.

It may be anticipated that each organization (college) will be pursuing change under a unique combination of factors depending upon its history, governing structure, relationship with government, location, client demand, etc. The matrix described above will direct the data-gathering process in a manner to reveal the particular forces at work and the direction of the change process.

The last task was to organize the data-gathering process in such a way as to ask the "right" questions of the "right" individuals so as to provide answers to the primary questions. That is, to ask: In which way are community colleges responding to the economic and socio-political changes of the nineteen-eighties? Who is influencing these changes? To what extent are colleges remaining consistent with their traditional missions?

\section{METHODOLOGY}

Having established a conceptual model upon which to base the data-gathering process, the next task in the study was to design an investigative method. This step involved two phases. The first was to determine the goals currently held for community colleges in all regions of Canada by two key constituent groups, the personnel in government ministries responsible for colleges, and chief executive officers, and to analyze their ranking and rating of these goals. This first phase of the study has been already reported (Dennison and Levin, 1988).

The second phase, which forms the basis of this paper, involved an intensive study of fourteen community colleges across Canada from most provinces and territories. From the provinces with large college systems (British Columbia, Alberta, Ontario, and Quebec) two colleges, one urban and one rural, were selected.

Data were collected from the selected colleges in a systematic format. Responses from key constituent groups (presidents, board members, administrators, faculty, support staff and students) were elicited by an instrument which produced information on changes and outcomes of changes, within the selected time-frame in the following areas:

a. Education programs

b. Students 

c. Teaching and support staff
d. Administration and administrators
e. Curriculum and instruction
f. Delivery of instruction
g. Accessibility
h. Governance
i. Advisory bodies
j. Relations with government
k. Personnel relations
1. Finance
m. Relations with community

Published and non-published information pertaining to each college (e.g., planning reports, budgets, enrolments, and collective agreements) were also gathered and analyzed. Furthermore, on-site interviews were conducted with key personnel at each institution as a means of supplementing or clarifying the data which had been already generated. Both the data-gathering instrument and the nature of on-site interviews were generated from the theoretical framework as previously described.

Collected data were used to develop descriptions of change in each of the fourteen colleges. From these descriptions the theoretical perspectives were applied as ways of categorizing the colleges. The categories indicate the kinds of institutions which are emerging in the 1980 s and were expressed under the descriptions of functions, missions and goals. The categories also indicate organizational behaviours which direct action (or changes) and the actions (or changes) themselves. These are expressed as power configurations and adaptation.

Finally, the study identified and described those common trends in the selected sample which may be classified as organizational changes in Canadian community colleges, during the last five years.

\section{OBSERVATIONS AND CONCLUSIONS}

\section{Forces of Change in Canada's Community Colleges}

This section of this paper analyzes the forces which are influencing change in Canada's colleges in the 1980 s, the scope and direction of change, and the extent to which colleges have retained or modified the goals and purposes upon which they were established. While numerous, the primary influences upon change emanate from governments.

At the federal level, the diversion of funds for vocational training from public institutions to the private sector has triggered a series of responses from the former. Activities pursued by the colleges include enterpreneurialism, a search for alternative funding sources with more contracting of services, and discontinuation of some programs, with "privatization" of others.

Provincial governments have also exerted increasing influence upon college activities, either by direct control over program development, or through funding 
formulae which stimulated greater productivity, efficiency and accountability. Colleges were expected to emphasize economic rather than social goals. A more direct relationship between the colleges and their appropriate provincial ministries was by far the most significant precursor of change which emerged during the study. Most of the other activities, at the administrative, board, instructor, or program level, originated in response to provincial government action in one form or another.

Community pressures, largely from employer groups, tended to focus upon the need for more convenient, flexible programs for upgrading personnel in the workplace. In general, college programs suffered from erratic demands, as apprenticeship and certain technologies became less popular, and computer related, business, renewable resources, and service programs began to attract higher enrolments.

Pressures from other educational institutions upon colleges varied by region. In general, universities and technical institutions were becoming more selective with regard to transfer students, largely through the exercise of admission quotas. However, there were also more cooperative efforts to develop programs which articulate among institutions.

Pressures for change from internal constituencies within colleges were also evident. Administration is generally concerned with initiation of change through refinement of the college mission. Funding difficulties have created an ongoing need to set priorities, eliminate low appeal or non-funded programs, pursue contracts with industry, establish self-financing programs, including those involving international contacts, and in general, to find ways to increase productivity within the organization. Much of this activity is driven by fiscal rather than educational considerations. The demand for better and more sophisticated management skills proved to be a stimulus for more professional development of administrators.

References to leadership occurred frequently, and it was obvious that the role of the chief executive officer was critical. This role had several dimensions, not the least important being the "status" of the president with the provincial authorities. Several times the "political" power (e.g., prestige with the Minister, relationship with the board, and status with the faculty) of the CEO was referred to as a key determinant of organizational change. It would not be an exaggeration to state that the overall morale of any college rested upon the reputation of the president and that individual's perceived role as an educational leader.

By contrast, the role of the Board of Governors in the initiation of change was limited. As the influence of the provincial ministries expanded, the authority of the boards seemed to diminish. Several board members expressed a concern over evaluation of instruction and management, but few specific actions were noted.

Pressures from teaching faculty and staff groups were exerted, primarily through the collective bargaining process. Concern over job security is itself a formidable obstacle to change. Program discontinuation, distance learning, course rationalization, and demands for greater productivity were all perceived as threats 
to job security. An increase in the number of part-time instructors was perceived as having mixed consequences.

Human resource development, in the sense of renewal and revitalization, is an issue prominent in every region of Canada. The aging faculty and staff, the lack of advancement opportunities, and the stagnant job market for college teachers have all become factors in institutional change. As a result of funding constraints, however, professional development activity is modest. Instructors are being encouraged to become more productive, utilize computer-related instructional methods, deal with modularized learning arrangements, make better use of instructional time, accommodate more students in different ways, and improve instructional quality - all of which are seen as means of instructor development.

A changing profile of the student population has brought additional pressures upon the colleges. The "pool" of traditional college-age (18-21) students is decreasing slowly and colleges have had to recruit more mature students to maintain enrolment in some programs, particularly in the technology area. Mature students are more inclined to pursue part-time studies, and colleges have had to adjust to the changing needs of a new clientele by reorganizing many programs. Under-preparation is not confined to mature students. Many colleges expressed concern over the skill, particularly in the area of communications, displayed by high school leavers. Some colleges saw themselves as having to provide unanticipated remedial education.

In addition to having to respond to the needs of adult learners, colleges face additional pressures from policies designed to accommodate specific groups (e.g., disabled, multicultural and women) in non-traditional programs. The adjustments needed to deal with the changing student clientele extend into the counselling, instructional, and organizational components of the colleges. These pressures are exacerbated by the budget reductions.

\section{Orientations of Canadian Community Colleges}

Table 1 displays the placement of fourteen (14) Canadian community colleges under the categories of functions, missions, goals, adaptation, and power configuration. Variability characterizes the fourteen colleges. In their missions and functions, these colleges correspond to four of Cross' (1985) five options, and they are equally divided on their mission focus (McCartan, 1983). Their goals are diverse but are consistent with identified functions and missions for each college. In adapting to the external environment, these colleges rely on three of the four approaches noted by Cameron (1984). Power behaviours in these colleges span the range of Mintzberg's (1983) power configurations, if not as a dominant type (e.g., closed system) then as a minor or secondary type (e.g., autocracy).

In order to illustrate the colleges' categorical placements, a brief discussion of two institutions follow. This discussion will explain the categorical labels associated with these colleges. 
TABLE 1

ORIENTATIONS OF CANADIAN COMMUNITY COLLEGES

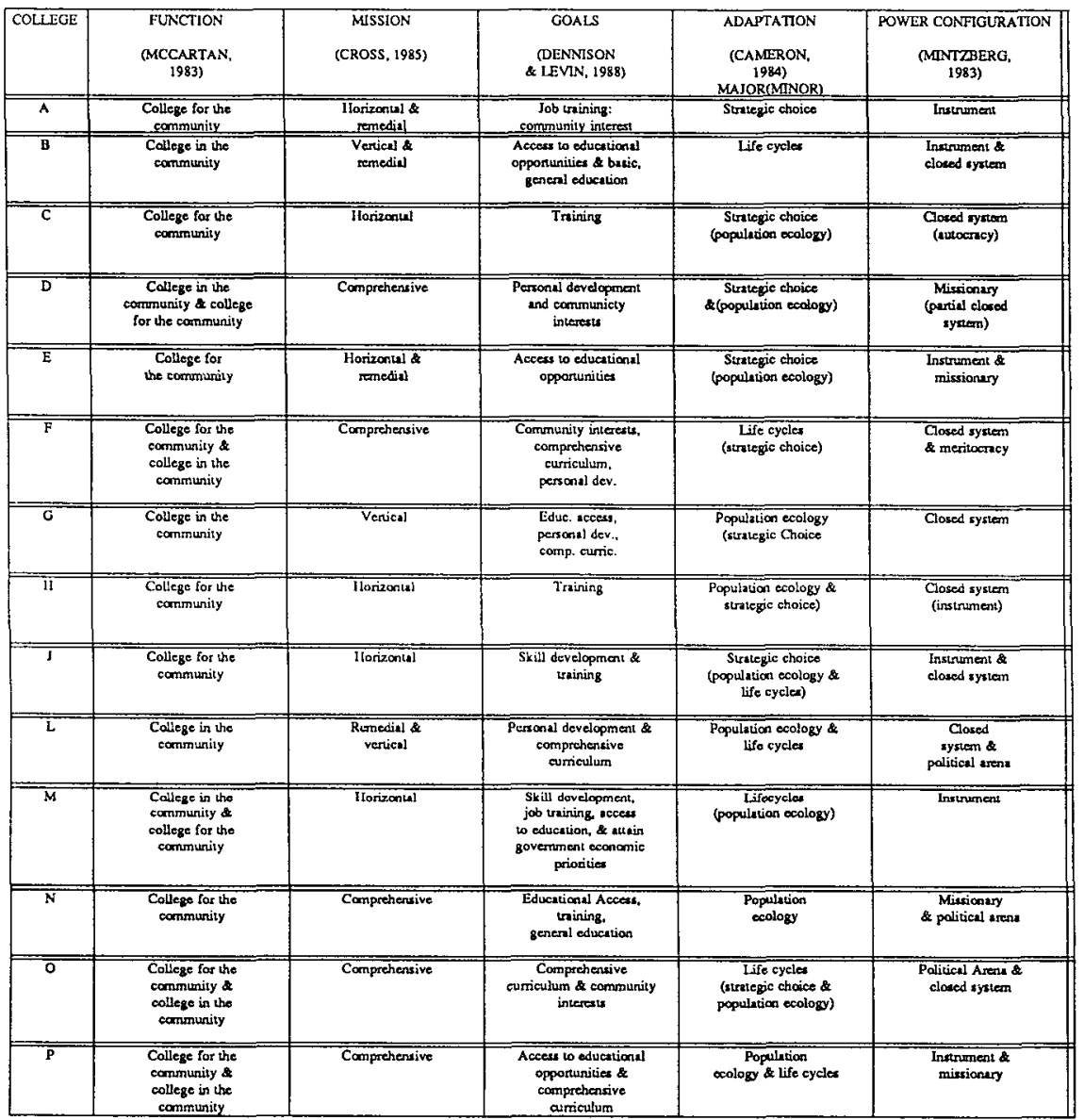

\section{COLLEGE $F$}

College F, established in the late 1960s, enrols approximately 1865 full time equivalency students in credit programs. The annual budget in 1987 was 14.7 million. College $F$ is located in Western Canada.

College $\mathrm{F}$ does not address forces of change in the external environment. At the senior management and board level there is little concern over college directions. At the faculty level, the focus is on a potential for the college to obtain degree-granting status. The college is not prepared for externally imposed change, such as government funding decreases, or population decline. Nor is the college 
prepared for internal strife such as labour relations conflicts, which often follows externally stimulated changes.

The college's goals, missions, and functions suggest a balance between individual and community needs, with an emphasis on upward social and economic mobility for community members. With an increase in aging faculty, institutional maturity, and local conservative tendencies, the college has moved into a stage of formalization of roles and processes. Organizational change is, in this sense, either resisted or curtailed. Change is also curtailed because two major power behaviours, rather than one, work at directing or controlling the organization. One behaviour stems from the faculty orientation toward a more prestigious institution, a shared belief which influences institutional management and governance. A second behaviour stems from the orientation of senior administration and the governing board. This is a community-focussed orientation which suggests that the colleges serves the local community's needs (rather than their ambitions or those of internal constituents). The two orientations co-exist, and the college largely ignores external forces of change.

\section{COLLEGE H}

College $\mathrm{H}$, established in the late 1960 s, enrols approximately 10,000 full time and 25,000 part-time students in adult programs. The annual budget in 1986 was approximately $\$ 80$ million. College $\mathrm{H}$ is located in Eastern Canada. College $\mathrm{H}$ has experienced considerable pressures from forces both external to the college and within the college. External forces include decrease in federal government funding, changing patterns of enrolment, and reduction of traditional college age population. Internally, the college has increased its emphasis on a managerial style of governance.

College H's goals, missions, and functions focus on job training for a broad cross-section of a large metropolitan community. With loss of federal funding, the college relates to the community as a source for funds as well as clients for college services. The external forces of change have had serious consequences. With reductions in available funds, the college has altered both its approach to some instructional delivery methods, including the use of computer-assisted instruction and self-paced learning, and the duration of programs. The college, on the one hand, is chosen by students because of its job training focus; on the other hand, the college adapts in order to attract students. The college serves two major groups: government and students (or potential students). Senior management directs College $\mathrm{H}$ toward system goals of survival, efficiency, control, and growth. Lack of funding does direct approaches to educational programming and operations, but the internal structure and processes direct institutional behaviours. There is increasing attention by administrators to efficiency and survival, as opposed to quality and effectiveness. Caught between several forces of change, College $\mathrm{H}$ is in a state of flux.

While there is apparent variation in the orientation of Canadian community colleges, which can be seen in Colleges $\mathrm{F}$ and $\mathrm{H}$, there are also common features. 
The fourteen colleges have taken several different approaches to adaptation, but none can be identified with Cameron's (1984) symbolic approach. The colleges' power behaviours, while covering all six of Mintzberg's (1983) types, show only one example of a meritocracy (College F), and one example of an autocracy (College $\mathrm{C}$ ). In both cases, another power configuration is present (i.e., closed system). Both the community of scholars and the single autocratic ruler are anomalies, whereas the instrument configuration is visible in seven colleges, and the closed system in nine. These adaptation and power configuration labels accompany goals which are, in the main, related to employment preparation ( 7 cases) and to educational access ( 6 cases). The employment preparation goals are accomplished by missions which fall under Cross' (1985) category of the horizontal focus ( 5 cases); and the access goal is accompanied by Cross' (1985) category of the vertical or comprehensive focus (4 cases).

Nonetheless, these colleges are not identical or synonymous organizations. They have different functions, missions, and goals. They adapt to the environment in at least four different ways or combinations of approaches; and they display great variation in their organization power behaviours. Although actions and behaviours fall within a limited range, these taken together suggest an individual orientation for each college.

\section{Developmental Principles and Change in Canada's Community Colleges}

Finally, it seems important to discuss the results of the study with regard to the extent to which the selected colleges have modified or reasserted the goals and purposes upon which they were originally established. As described earlier in this paper, five key "principles" were drawn from the literature. These principles represented the common bases upon which all college systems in Canada were constituted. In the following pages, the status of each principle will be discussed in the light of the data gathered in the study.

\section{FLEXIBILITY}

There is little doubt that colleges have adapted, and are adapting, to change. New clienteles have been attracted to replace the diminishing pool of 18-21 year olds. Modularized, computer-assisted instructional technology is increasing. Colleges are accommodating more students through contract services and part-time studies, while raising productivity of performance. Many traditional programs have been abandoned and replaced by others more suited to an evolving, dynamic marketplace.

Rather than being driven by a desire to raise the quality of college education, however, or by a commitment to improve teaching, changes brought about by various adaptations seem to be the products of economic necessity, such as constrained budgets and funding formulae which demand increased services at lower costs. Colleges attempt to preserve their budgets, gather additional funding, and seek to maintain program quality and educational credibility. 


\section{ACCESSIBILITY}

The evidence gathered in this study was mixed. Colleges are making efforts to attract an alternative clientele to traditional high school leavers; in most regions this alternative consists of mature, part-time students, the majority of whom are women. However, strategies to attract these new students are not entirely open-ended. Policies generated from government, which translate into funding, are normally tied to selected programs for selected individuals. Adult upgrading and vocationally specific or contract programs are eligible for fiscal support, and it is in these areas that the mature student clientele is normally found to cluster. Governments are less inclined to subsidize credit-free programs of a personal, recreational, or cultural nature. In some regions, academic or general education courses are given limited financial support with funding formulae, and student access as a consequence is either limited or reduced.

Although there is a great deal of support articulated for programs aimed at specific minority groups (e.g., physically disabled, senior citizens, native people), there appears to be few concrete program initiatives designed for such groups. While there are initiatives underway in non-conventional learning approaches, in academic upgrading, and for targeted groups of the unemployed, access is pursued on a fairly selective basis. The conventional adage of the sixties and seventies, that colleges would provide learning opportunities for all, must be regarded as no longer applicable.

\section{COMPREHENSIVENESS}

Funding priorities set by both provincial and federal governments are not designed to stimulate purely academic or more general educational components of college curricula. In provinces where academic (or university equivalent) programs are offered, student demand is high but funding is such that increased productivity (larger classes, reduced course content) is necessary to ensure continuation of sufficient offerings to meet demand.

Funding pressures are also influencing curriculum changes in technological and career-vocational programs. In several provinces, course content was revised to reduce the number of hours of instruction, and programs were limited in their range of offerings, particularly in the elective categories.

Credit-free community education is expected to be, or become, self-supporting in most of the colleges studied. The inevitable reduction in credit-free offerings can also be viewed as a further limitation of the reality of a comprehensive curriculum. Government funding priorities are seen as the major source of erosion of the comprehensive community college curriculum.

\section{TEACHING}

College personnel, at both the instructional and the administrative levels, place the highest priority upon the teaching and learning function of the colleges. While the intent remains strong, however, there are obstacles to effective instruction. Pressure to serve more students at lower costs, insufficient support services for 
modularized and individualized instruction and distance learning, and problems created by wide ranges in student abilities are viewed as impediments to high quality teaching and learning.

The entire concept of learning, teaching, and student service is under review. While there is introduction of newer instructional techniques, many instructors are wary of the advantages promoted by these methods. Funding priorities are not favourable to student services (e.g., counselling and academic support). As well, there is evidence of an aging and seemingly tired instructional staff in colleges. Nevertheless, instructional staff express concern for students and a personal commitment to teaching.

\section{COMMUNITY FOCUS}

In reaction to an increase in centralization of control at the provincial level, colleges are driven toward improved community links. Faced with increased pressures from government, colleges seem to have a sense of political ineptitude in trying to promote their case. By widening a base of support and for strengthening their voice in the corridors of power, colleges have been seeking political allies. Consequently, many colleges are engaged in pursuing links with community groups - employers, potential students, social organizations, and local government - in an effort to broaden support in an essentially political arena. In a fashion, this activity is strengthening the community function of colleges, although not necessarily for the most altruistic of reasons.

In spite of the above, colleges in most regions of Canada have become provincial rather than community in their orientation. Specifically, it is the nature of the curriculum which best confirms this conclusion. Programs reflect provincial far more than community interests in their design.

\section{Colleges For the Community or Colleges in the Community?}

Canada's colleges are no longer young. In fact, they have matured rapidly. With maturity has come a series of changes, both cosmetic and fundamental. Differentiation among the colleges in this regard seems to be based upon the stage of an individual college's evolution and its relationship with the provincial government.

Colleges have become institutions less for the community and more social organizations in the community. With few exceptions, they have become essentially provincial institutions, marching to a rhythm emanating from the relevant government ministry. Vocational preparation, in the form either of specific job training or the upgrading necessary to prepare an individual for training, has become the overriding priority in most provinces. Ironically, there is little supporting evidence to show that this priority meets the needs and goals of the colleges. 
While colleges remain essentially on the path which guided them in their earliest years, this path has become increasingly narrow, mostly uphill, and more precipitous than in the past. Nevertheless, colleges continue to be seen as opportunities for thousands of Canadians from all backgrounds who seek further education and training in preparation for an unpredictable and challenging future.

\section{REFERENCES}

Cameron, K.S. (1984). Organizational adaptation and higher education. Journal of Higher Education, 55(2): 122-144.

Cameron, K.S. \& Whetten, D.A. (1981). Perceptions of organizational effectiveness over organizational life cycles. Administrative Science Quarterly, 26: 525-544.

Cross, K.P. (1985). Determining missions and priorities for the fifth generation. In W. Deegan, D. Tillery, and Associates (Eds.) Renewing the American Community College. San Francisco: Jossey Bass.

Dennison, J.D. (1987). Colleges and governments: An evolving relationship. in Governments and Higher Education. Toronto: OISE Press.

Dennison, J.D. (1986). \& Gallagher, P. Canada's community colleges. Vancouver: University of British Columbia Press.

Dennison, J.D. \& Levin J. (1987). Goals of community colleges in Canada: A 1987 perspective. Canadian Journal of Higher Education, 18(1): 49-63.

Dennison, J.D. \& Levin, J. (1988). Canada's community colleges in the nineteen eighties. Toronto: Association of Canadian Community Colleges.

Dill, D. (1982). The management of academic culture. Higher Education, 11(3): 303-320.

McCartan, A. (1983). The community college mission. Journal of Higher Education, 53(6): 666-692.

Miles, R.E. \& Cameron, K. (1982). Coffin nails and corporate strategies. Englewood Cliffs, NJ: Prentice-Hall Inc.

Miles, R.E. \& Snow, C.C. (1978). Organizational strategy, structure and process. Toronto: McGraw Hill Book Company.

Mintzberg, H. (1979). Organizational power and goals: A skeletal theory. In D. Schendal \& C. Hofer (Eds.) Strategic Management (pp. 64-80) Toronto: Little, Brown and Company.

Mintzberg, H. (1983). Power in and around organizations. Englewood Cliffs, NJ: Prentice Hall Inc.

Pfeffer, J. (1982). Organization and organizational theory, Boston: Pitman. 
